\title{
Ruler of Interests, Political Interests, or Law Enforcement: Case Study of Amnesty Plan for Din Minimi Group in East Aceh
}

\author{
Yusi Amdani \\ Fakultas Hukum Universitas Samudera, Langsa Aceh \\ e-mail:yusiamdani@yahoo.co.id
}

\begin{abstract}
The aim of this paper is the concept of the settlement of criminal cases committed Din Minimi Group. The amnesty is the prerogative of the President specified in the Constitution of 1945. Amnesty NRI is a form of pardon to political prisoners to be free from legal sanctions. The legal basis for amnesty stipulated in the Emergency Law No. 11 of 1954 on Amnesty and Abolition. The method used in this paper is a conceptual approach. Related to peace efforts in Aceh, the President has issued Presidential Decree No. 22 of 2005 on Amnesty and Abolition against GAM members. Once that happens again insurgency by Din Minimi caused dissatisfaction with the policy of the Governing of Aceh. Counterinsurgency is done by giving amnesty to the group Din Minimi so willing to surrender. When viewed in this aspect of the law, amnesty if forced to give to Din Minimi, it is destructive to the prevailing laws in Indonesia. Do not rule out the possibility of regulation will hit Indonesia polemic, so the solution had to pay attention to various aspects of both of the victim, the offender, and the community by not disregard the rule of law and justice.
\end{abstract}

Tujuan penulisan ini adalah konsep penyelesaian kasus pidana yang dilakukan kelompok Din Minimi. Amnesti adalah hak prerogatif Presiden yang ditentukan dalam Konstitusi 1945. Amnesti NRI adalah bentuk pengampunan bagi tahanan politik untuk bebas dari sanksi hukum. Dasar hukum untuk amnesti diatur dalam UU Darurat No. 11 tahun 1954 tentang Amnesti dan Penghapusan. Metode yang digunakan dalam tulisan ini adalah pendekatan konseptual. Terkait dengan upaya perdamaian di Aceh, Presiden telah mengeluarkan Keputusan Presiden No. 22 Tahun 2005 tentang Amnesti dan Penghapusan Anggota GAM. Setelah itu terjadi lagi pemberontakan oleh Din Minimi menyebabkan ketidakpuasan dengan kebijakan Pemerintahan Aceh. Counterinsurgency dilakukan dengan memberikan amnesti kepada kelompok Din Minimi sehingga mau menyerah. Jika dilihat dari aspek hukum ini, amnesti jika dipaksa untuk diberikan kepada Din Minimi, itu merusak hukum yang berlaku di Indonesia. Jangan mengesampingkan kemungkinan regulasi akan menghantam polemik Indonesia, sehingga solusinya harus memperhatikan berbagai aspek baik dari korban, pelaku, dan masyarakat dengan tidak mengabaikan aturan hukum dan keadilan.

Keywords: amnesty; political interests; law enforcement 
Yusi Amdani

\section{Introduction}

Referring to the provisions of Article 14 Paragraph (2) the Constitution of the Republic of Indonesia, the Year 1945 that "the President gave amnesty and abolition by taking into consideration the House of Representatives". Amnesties that are owned by the President is a prerogative inherent in his position as head of state. Where the process of amnesty and abolition is done by taking into consideration of the Parliament.

In Indonesia, amnesty is one of the rights owned by the president in judicial matters. Amnesty together with the abolition of pardon and rehabilitation is a concept of forgiveness to a person or group of people who become a privilege which only the president as head of state. It is stated in the Constitution of the Republic of Indonesia, the Year 1945. Prior to the amendment of the Constitution of the Republic of Indonesia, the Year 1945, these rights are owned by the president unanimously, make the president look like a king or queen who has absolute power. ${ }^{1}$

However, after the holding of an amendment Constitution of the Republic of Indonesia Year 1945, the right to pardon the change to make room for other government officials for consideration. Amnesty is etymologically derived from the Greek word "amnestia" which literally can be interpreted as the "forgotten" or amnetos which means "forgetting".2 Penalties, as well as any consequences that may arise from the decision of the criminal law was eliminated meaning that these people have to get amnesty. ${ }^{3}$

The legal basis for granting amnesty as mentioned in Article 14 paragraph (2) of the 1945 Constitution passed down in the form of legislation, namely the Emergency Law No. 11 of 1954 on Amnesty and Abolition. The difference between amnesty and abolition is this: 1) By granting amnesty then all due to those mentioned above should be abolished; ${ }^{4} 2$ ) By giving the abolition of the prosecution of the people was abolished.

\footnotetext{
${ }^{1}$ Indra Prawira, "Amnesti dan Abolisi dari Perspektif Hukum Tata Negara," in Seminar Pengusulan Syafrudin Prawiranegara Sebagai Pahlawan Nasional, Bandung, 16Juni 2009 (Bandung, 2009), 2.

${ }^{2}$ Darmanto, et al, Sistem Administrasi Negara Kesatuan Republik Indonesia (Jakarta: Universitas Tebuka, 2007), 31 .

${ }^{3}$ Anonimous, "Mempertimbangkan Amnesti bagi Tahanan Politik Papua” (Jakarta: Kontras, n.d.), 3.

${ }^{4}$ See the explanation of the Emergency Law No. 11 of 1954 on Amnesty and Abolition.
} 
Amnesty can be given before or after sentencing, have or have not done the investigation and inquiry related offenses charged. Amnesty is not given to one person, but to the people. Therefore the general amnesty granted to free those who tripped cases of a political nature and involve many people and has a profound impact on a government, for example, the cause of the brawl, riot, insurrection or illegal immigration.

Amnesty may be granted with a number of considerations. One is when the authorities feel that there is something more important than just punish people for actions that have past. For example, because of the services of someone so great for the country or for reasons of peace and the interests of the state. In the new leadership, amnesty is seen as an attempt to resolve the problems that occurred in the past. Amnesty granted after the war, for example, can help end the ongoing conflict. Or amnesty granted to the rebellion by the consideration that an amnesty would be able to stop the insurgency businesses and create a peaceful and conducive atmosphere and avoid the causes of acts of abuse of authority. ${ }^{5}$

Amnesty can eliminate the possibility of supporting the rebellion or political opponents to take revenge and fueled other conflicts. Amnesty used as a tool to reach an agreement. In a number of dispute settlement, amnesty made on condition that the other party to give up. The use of amnesty also can prevent a country from a massive prosecution conducted by the people. A number of political prisoners often regarded as a hero by his supporters because it has great merit in the fight for the rights of the communities that support them.

In relation to amnesty, specific to the regions of Aceh province has its own storyline in the State Indonesia. Besides incised gold ink in the early days of independence Indonesia, Aceh is also dogged by stories about some of the uprising, both in the early era of the old order, the new order to reform. The last time the action is considered a rebellion by the government for Aceh Sumatra National Liberation Front (GAM), which requires separate themselves from the frame of the unitary state of Indonesia. Until the settlement process is done by setting the MoU between the Government of Indonesia and GAM. ${ }^{6}$

5Darmanto, et al., Sistem Administrasi Negara Kesatuan Republik Indonesia, 32.

6Zaki 'Ulya, "Refleksi Memorandum of Understanding (MoU) Helsinki dalam Kaitan Makna Otonomi Khusus di Aceh," Jurnal Konstitusi 11, no. 2 (2014): 371-92, https://doi.org/ $10.31078 / \mathrm{JK} \% \mathrm{X}$. 
Yusi Amdani

Referring to the history, precisely in 2005, President Susilo Bambang Yudhoyono issued Presidential Decree No. 22 of 2005 on Amnesty and Abolition Of More Than 2000 Members of the Aceh Sumatra National Liberation Front (GAM). They then organized themselves into a local party and win in the elections, even one of the GAM leaders now serves as the governor of Aceh. ${ }^{7}$

Amnesty policy in Aceh does not just end with the promulgation of Presidential Decree No. 22, of 2005. However, the current movement emerged a group of people in Aceh who opposed the policies of the Government of Aceh and the central government itself. The armed group led by Nurdin Ismail, known as Din Minimi. ${ }^{8}$ Right at the date of December 28, 2015, Din Minimi surrender was followed by 120 of his men, and then handed over 15 weapons. Step negotiations with the Minimi Din group are done because according to government policy that emphasizes "subtle approach" (soft approach) in the face of separatist groups or armed groups. On the form of the good faith of the Minimi Din, the government provides compensation in the form of direct Presidential amnesty. ${ }^{9}$

On the one hand, a series of actions Din Minimi at the time of taking up arms and fight, indicated a strong entry into the criminal act (crime). Base arguments based on data from the Aceh Police Department stating that on July

7Problems that arise after the peace agreement GAM-GoI it is an internal conflict between former GAM members to compete for the strategic position of local government in Aceh. International Crisis Group. Report No. 135 "Indonesia: Averting Election Violence in Aceh,” International Crisis Group, 2012, https://www.crisisgroup.org/asia/south-east-asia/indonesia/indonesia-averting-electionviolence-aceh; Report No. 123 “Indonesia: GAM vs GAM in the Aceh Elections," International Crisis Group, 2011, https://www.crisisgroup.org/asia/south-east-asia/indonesia/indonesia-gam-vs-gamaceh-elections.

8Referring to media sources mentioned that Din Minimi disagreements with other KPA board when the elections of 2012. At that time, the couple brought the KPA GAM leaders Zaini Abdullah and Muzakir Manaf. While docked to the Minimi Din Muhammad Nazar, former vice governor of Aceh who advanced to the arena gubernatorial elections in 2012. Since then, Din choose his own path. Long since disappeared, the name was later associated with a number of criminal acts in East Aceh. Until then he makes a scene by appearing in newspapers and scathing criticism against the Government of Aceh which is actually a leader in the fight against the central government which have been regarded as unfair to Aceh, See Peuhaba, "Riwayat Lengkap Din Minimi di Aceh," Detik Semas $\alpha, 2015$, https://seaceh.wordpress.com/2015/03/27/riwayat-lengkap-din-minimi-di-aceh/. Accessed May $2^{\text {nd }} 2016$.

${ }^{9}$ Tim Liputan BBC News Indonesia, "Kelompok Eks Kombatan GAM, Din Minimi Menyerahkan Diri," BBC News Indonesia, 2015, Accessed May 5, 2016, https://www.bbc.com/indonesia/ berita_indonesia/2015/12/151229_indonesia_kelompokdimini_menyerah.. 
16, 2013 until August 5, 2015, the number of criminal acts committed already 12 cases, generally is kidnapping and extortion. Illegal possession of fire weapon in the hands of Din Minimi and his group also entered the category of crimes under Law No. 12/DRT/1951 on Firearms. ${ }^{10}$ So that the data refer to the crime committed by Din Minimi of Aceh Regional Police, appeared arguments from several parties questioned the feasibility of granting amnesty. The amnesty where one side has ruled out criminal offenses (crimes) committed by Din Minimi.

On the basis of the description above, this study will be raised several issues related to the formulation of amnesty for Minimi Din and his group. The formulation of the issues raised include are: 1) What is the legal basis in legislation Amnesty Indonesia? 2) How can the impact of granting amnesty in Din Minimi assess according to the legal aspects in Indonesia? 3) What are the considerations in the enforcement of criminal law in the case of Din Minimi?

Based on the scope and identifying problems as noted above, to examine in a comprehensive and holistic point, be searched by using the type of normative juridical research, namely legal research conducted by examining the substance of legislation, and supported by the existing literature on the subject problems discussed. ${ }^{11}$

\section{Analytical Study on Granting Amnesty Din Minimi in East Aceh}

\section{Theory of Criminalization in Islamic Law}

Every country certainly has a different legal system. One area of law is criminal law. In Indonesia itself there are some differences in the legal system. For example in Indonesia today there are laws that apply formally as well as customary law and Islamic law. Indonesia is predominantly Muslim. And in some regions in Indonesia, Islam is not only an official religion, but even the law that applies in that area is Islamic law. So from here it can be seen that there is a desire from among the Muslims that in real terms the majority can

\footnotetext{
10Aryos Nivada, "Amnesti Bagi Din Minimi, Layakkah?," aceHTrend.com, 2016. Accessed May 6 . 2016., https://www.acehtrend.com/2016/01/04/amnesti-bagi-din-minimi-layakkah/.

${ }^{11}$ Soerjono Soekanto, Pengantar Penelitian Hukum (Jakarta: UI Press, 1986), 12.
} 
live according to their religion. And one of the provisions of Islamic law is Islamic criminal law. ${ }^{12}$

In Islamic criminal law about the theory of punishment can be known from the purpose of the imposition of criminal, where this can be formulated from the objectives of each criminal in Islamic criminal law, namely the purpose of hudud, qishas diyat and ta'zir. In Indonesian criminal law the theory of punishment is known as 3 theories namely absolute theory, relative theory, and combined theory.

Ahmad Syafiq, mentions in his writing that Islamic Criminal Law is a law that lives in Indonesian society and that Islamic Criminal Law can apply or color in the criminal law arena in Indonesia, it is necessary to have a reconstruction of Islamic Criminal Law specifically in terms of punishment. ${ }^{13}$

The purpose of the conviction in the Islamic Shari'ah is the realization of the purpose of Islamic Law itself, namely in retaliation for evil acts, general prevention and special prevention and protection of the rights of the victim. Another definition states that punishment is an affliction imposed on someone as a result of his actions violating the rules. Criminalization with certain penalties is intended to bring benefit to the people and prevent tyranny or adversity. When the purpose of punishment is to improve the individual, safeguard the community, and maintain their lives, punishment must stand on a basic value that can realize these goals so that punishment can fulfill the task that should.

So that the basic principle to achieve the objectives of the crimes mentioned above, can be made into several criteria as follows: 1) The punishment is universal, that is, it can stop people from committing a crime, can raise awareness and educate the perpetrators. 2) The application of the sentence material is in line with the needs and benefits of the community. 3) All forms of punishment must be able to guarantee and achieve personal and community benefit. 4) The sentence aims to make improvements to the offender.

\footnotetext{
${ }^{12}$ Herawati Susetyorini, "Perbandingan Teori Pemidanaan Menurut Hukum Pidana Islam dan Kitab Undang-Undang Hukum Pidana (KUHP)” (Thesis, Universitas Muhammadiyah Malang, 2004), http://eprints.umm.ac.id/19720/.

${ }^{13}$ Ahmad Syafiq, "Rekonstruksi Pemidanaan dalam Hukum Pidana Islam (Perspektif Filsafat Hukum)," Jurnal Pembaharuan Hukum 1, no. 2 (2014): 178-90, https://doi.org/10.26532/ jph.v1i2.1484.
} 
Meanwhile in the viewpoint of wisdom of Islamic law it is stated that the Islamic Shari'ah was revealed by Allah to benefit human life both concerning personal life and community life, one's life is expensive because it must be protected and protected by the provisions of the law Qishash has strong reliance to protect humans so Criminals arose because of having to bear the burden that would befall him if he committed the act.14

The Islamic Criminal Law System, legal and judicial gaming opportunities are very small. especially because, the criminal system of Islam is spiritual, that is, carrying it out means fearing Allah. Judges who cheat in imposing punishments, or accepting bribes in judging, face severe penalties by Allah, ie go to hell or even become infidels (apostates). The Prophet said: "Akhdhul amìri suhtun wa qabūl al-qādiy al-rishwata kufrun." (Prizes received by a ruler are sight (harām) and bribes received by a judge are kufr). ${ }^{15}$

\section{Basic Law of Amnesty Legislation in Indonesia}

In a Presidential system of government, there is the prerogative of the President as Head of State and Head of Government. However, due to the strength of the President authority, raised the issue so that the tendency is too strong authority and power in the hands of the President sought to be restricted. The President's power restrictions do with the Amendments to the Constitution of 1945.

Head of State or the President are considered authoritative in terms of granting pardons, amnesty for the benefit of abolition and restore justice to the impact of suffering inflicted by a court ruling against the behavior of criminal acts that have been proven legally in the judicial process before. However, a presidential system does not distinguish between the two types of positions, the authority attributed to the President who is the Head of State and Head of Government at the same time. ${ }^{16}$

As we know that amnesty, pardon, abolition and rehabilitation is an absolute right owned by the President, known as the prerogative. Prerogative

${ }^{14}$ Teungku Muhammad Hasbi Ash-Shiddieqy, Filsafat Hukum Islam Oakarta: Bulan Bintang, 1975), 177.

${ }^{15}$ Abdul Rahman Ritonga, Ensiklopedi Hukum Islam (Jakarta: Ichtiar Baru Van Hoeve, 1997), 1972.

16Jimly Asshiddiqie, Konstitusi dan Konstutionalisme Indonesia (Jakarta: Sinar Grafika, 2010), 184. 
is the right of the President as Head of State to issue a decision, on behalf of the State shall be final, binding and legally enforceable. The prerogative is the right of the highest available and provided by the Constitution for the President as Head of State. ${ }^{17}$

According to Merriam Webster Dictionary, the prerogative is an exclusive or special right, power, or privilege: such as 1) one belonging to an office or an official body; 2) one belonging to a person, group, or class of individuals, 3) one possessed by a nation as an attribute of sovereignty".18 Referring to the definition, in its function as a figure "can do no wrong", the President in the case as head of state has special powers or privileges that are not owned by any other state office functions. ${ }^{19}$

However, as the law does not concretely define, except in Article 1 point 9 of Law No. 27 of 2004 on Truth and Reconciliation Commission ${ }^{20}$, mentioned: amnesty is forgiveness given by the President to the perpetrators of gross human rights violations by taking into consideration the Parliament.

Meanwhile, according to Gayus Lumbuun to the book Abdul Ghoffar states an amnesty is a form of forgiveness given by the President as forgiveness by removing the right of prosecution of public prosecutor against a person or a group of criminal suspects is not necessary prosecutions. In general amnesty granted by the head of state to the perpetrators of political crimes, not the general crime. ${ }^{21}$

As the provisions of Article 14 Paragraph (2) NRI Constitution of 1945 states that "The President gave amnesty and abolition by taking into consideration the House of Representatives", amnesties carried out by the President as head of state by taking into consideration the Parliament. The

\footnotetext{
17Hendarmin Ranadireksa, Visi Bernegara Arsiktektur Konstitusi Demokratik (Bandung: Fokus Media, 2009), 198.

18“Prerogative | Definition of Prerogative," Merriam-Webster, accessed May 8, 2016, https:// www.merriam-webster.com/dictionary/prerogative.

${ }^{19}$ Dhian Deliani, "Pelaksanaan Kekuasaan Presiden dalam Pemberian Grasi: Studi terhadap Pelaksanaan Pemberian Grasi oleh Presiden Susilo Bambang Yudhoyono Tahun 2004 s/d 2010" (Thesis, Fakultas Hukum Program Pascasarjana Universitas Indonesia, 2011), 112.

20This law was repealed after the Constitutional Court Decision No.006/PUU-IV/2006.

${ }^{21}$ Abdul Ghofar, Perbandingan Kekuasaan Presiden Indonesia setelah Perubahan UUD 1945 dengan Delapan Negara Maju (Jakarta: Kencana Prenada Media Group, 2009), 105-106.
} 
significance of the notice means listening, studying, either directly through the oral or in writing on certain considerations both legally and politically issued by the Parliament to the President. This means that Parliament as an institution controlling the policies of the President may ask the President to relearn subject matter of amnesty to be granted to perpetrators of political crimes.

Bagir Manan in his view mentioned that pardon, amnesty, abolition, and rehabilitation is seen as a constitutional power of the President in the field of judicial owned, so it is associated with the participation of other institutions, namely the Supreme Court and Parliament in providing the legal and political considerations. Aside from the legal and political considerations there is also the consideration of human, social, and the other is the content of the prerogative of the President. ${ }^{22}$

Based on the description, the emergence of the controversy can't be separated from the two perspectives of law and politics. Politically consideration is one of them when the ruler (president) feel there is nothing more important than simply punishing people for past actions. For an example, the reasons for peace and the interests of the state. So also given to the rebels to stop the uprising and create a peaceful and conducive atmosphere and prevent abuses of authority.

Amnesty under consideration will be given to Din Minimi by the President, in addition to their pro opinion against the policy, appears also to be counter opinion. As reported by the Print Media renowned in Aceh said that amnesty by the President to the group Din Minimi rated by the former Chief of Strategic Intelligence Agency (BAIS) TNI Centre, Soleman B. Ponto can create a bad precedent for security in Aceh so that it will damage the reputation of Aceh. Granting amnesty to Din Minimi is not appropriate, because it is done is a criminal act and their actions do not compromise the security of all Aceh. ${ }^{23}$

As one item MoU which states that any form of firearm used by GAM during the conflict should be handed over to the AMM (Aceh Monitoring

\footnotetext{
22Bagir Manan, Lembaga Kepresidenan (Jakarta: FH UII Press, 2003), 166.

${ }^{23}$ Hasyim, "Amnesti untuk Din Minimi Hancurkan Reputasi Aceh," Serambi Indonesia Aceh.Tribunnews.com, 2016, accessed May 6, 2016, http://aceh.tribunnews.com/2016/01/02/ amnesti-untuk-din-minimi-hancurkan-reputasi-aceh.
} 
Mission) no later than December 31th 2006 . That is, if it has been passed from the date it then anyone caught using firearm it will be considered a crime. ${ }^{24}$

In contrast to the legal context, for the realization of legal certainty, the necessity for all offenders processed and proven guilt or innocence in court. Apart from that, constitutionally amnesty is the prerogative of the President as Head of State (not as a head of government) given to a person or group that committed a crime, which can accept or no consideration of the House, including the discourse of amnesty for Din Minimi and his group.

Although the amnesty is very functional for a democratic transition, the maintenance of peace and national reconciliation, the application still must meet certain prerequisites. In the perspective of human rights and international law does not justify granting amnesty which is contrary to the principles of justice that leads to Impunity. ${ }^{25}$ Various instruments (human rights and humanitarian law) requires the international obligations of the state to enforce the law (obligation to prosecute) against several serious crimes. ${ }^{26}$

Based on the description indicates that an amnesty related discourse (and /or abolition) to Din Minimi and the group, it can be categorized into crime (criminal) reasons / political motives. In the criminal context into the crimes against public order, as provided for in Chapter V of the Criminal Code Book II. Din Minimi group action also can't be said that crimes categorized separatism is, as members of Parliament, Effendi Simbolon. This, because they are not demanding separation/independence of the Homeland, but demand the rights and welfare of the Acehnese government, which actually does not require any armed action. ${ }^{27}$

\footnotetext{
${ }^{24}$ Hasyim.

25Impunity is a fact that legitimately grant exemptions or exemption from prosecution or punishment or harm to the person who has committed a violation of human rights. This usually occurs on the refusal or failure of a government to take or carry out legal actions against the perpetrators. Impunity can also be amnesty from government officials. Such measures are also an insult and not approved in the international law of human rights. ELSAM, "Impunitas," ELSAM Referensi HAM, 2014, accessed May 7, 2016, http://referensi.elsam.orid/2014/09/impunitas/.

${ }^{26}$ Amrizal J. Prang, "Kontroversi Diskursus Amnesti Din Minimi," Serambi Indonesia Aceh.Tribunnews.com, 2016, accessed May 7, 2016, http://aceh.tribunnews.com/2016/01/19/ kontroversi-diskursus-amnesti-din-minimi.

${ }^{27}$ Prang.
} 
Therefore, cases Din Minimi not only related penalties, but also political interests relationship central government and Aceh, despite the controversy necessity considered. Then to the central government and the Aceh administration in order to carry out the functions and duties welfare of the people of Aceh. Conversely, if these efforts have been done in order not to create a bad precedent law enforcement.

\section{Impact of Granting Amnesty Din Minimi in Legal Aspects}

the absolute right of the President. Changes to the provisions of Article 14 paragraph (2) of the Constitution year 1945 amnesty and abolition is aimed at improving the function and role of Parliament in monitoring the implementation of the rule by the President. With the provision of these considerations, the granting of a pardon, rehabilitation, amnesty, abolition is no longer the absolute right of the president, but must pay attention to the consideration of the Supreme Court or the Parliament.

in general amnesty given by the Presidential Decree policy, where the president serves as head of state. As last time granting amnesty for Aceh set forth in Presidential Decree No. 22 of 2005 on Provision of General Amnesty and Abolition To Everyone Involved in Aceh Movement.

As mentioned in the preamble weighing the decision of the President mentions that "that in order to realize national reconciliation in order to strengthen national unity, protection, fulfillment and promotion of human rights and to end the conflict permanently, needs to create a peaceful atmosphere throughout the whole of the province of Aceh Darussalam within the framework Unitary Republic of Indonesia under Pancasila and the Constitution of the Republic of Indonesia Year 1945; that in order to accelerate rehabilitation and reconstruction of the regions and people in the province of Aceh Darussalam as a result of the earthquake and tsunami, need the involvement and participation of all the potential strength of the nation; and that based on the considerations mentioned in paragraphs a and $b$, and to implement the Memorandum of Understanding between the Government of the Republic of Indonesia and the Free Aceh Movement, signed in Helsinki, Finland August 15, 2005, need to issue a presidential decree on the Granting of General Amnesty and Abolition against any person who involved in the Free Aceh Movement". 
Yusi Amdani

In the first dictum of Presidential Decree No. 22 of 2005 states that:

"Providing General Amnesty and Abolition to every person involved in the Free Aceh Movement, both inside the country and abroad, are:

a. Yet or have surrendered to the authorities;

b. Is or has finished undergoing training by the authorities;

c. Being examined or detained in the investigation, inquiry or hearing before the trial court;

d. Who had been sentenced, both who have or who have had permanent legal force; or

Developing or have completed a sentence in the Penitentiary."

Referring to the first dictum in connection with Minimi Din, Din Minimi is known that one of the GAM personnel in East Aceh who also participated in revolt during the conflict either martial law or civil emergency. However, as the foregoing, Din Minimi is one of the many members of GAM who received amnesty from the President by Presidential decree. It is also reinforced by the provisions of obiter two figures (1) which reads "By granting a general amnesty, then all the consequences of criminal law against any person referred to in the first dictum abolished". This means that all criminal acts committed by all personnel GAM had been abolished under the terms of the amnesty.

Controversy granting amnesty to Din Minimi today, raises the pros and cons due to Din Minimi with a criminal offense after the passing of the Presidential Decree No. 22 of 2005. As mentioned in the fifth dictum that "The granting of general amnesty and abolition void if the person referred to in the first dictum committed the crime of treason against the Government of the Republic of Indonesia after the date of enactment of this Presidential Decree". That is, actions Din Minimi and his group against the Government of Aceh, still considered as criminal offenses are usually punishable by applicable law.

In the legal aspect, if amnesty is forced to give to Din Minimi, it is destructive to the prevailing laws in Indonesia. Do not rule out the possibility of regulation will hit Indonesia polemic, because it will be a lot of lawyers protested against the decision granting the amnesty. Other impacts are felt on the law enforcement agencies namely the police. Public confidence deteriorated against the law enforcement process in Indonesia. The point will be a crisis of public trust in the efforts of law enforcement officials in enforcing the law in Indonesia. Another effect of the police institution that is publicly assesses that the entire work in law enforcement against Din Minimi and his group "lies" sheer, if amnesty is given as well. 


\section{The Considerations in the Enforcement of Criminal Law in the Case of Din Minimi}

Based on the theory that the development of the criminal law, also helped develop several theories about the purpose of punishment, ie the theory of absolute (retributive), the theory of relative (deterrence/utilitarian), the theory of incorporation (integrative), treatment theory and the theory of social protection (social defense). a Theories of sentencing to consider various aspects of the objectives to be achieved in the criminal punishment. ${ }^{28}$

Absolute theory (the theory of retributive), considers that punishment is retaliation for the mistakes that have been made, so the action-oriented and is located on the crime itself. Punishment is given because the actors have sanctioned it for the sake of his guilt. ${ }^{29}$ Furthermore, the theory of relative (deterrence), this theory is not looking at criminal prosecution in retaliation for the fault of the perpetrator, but as a means of achieving the worthwhile goal to protect society towards prosperity. This theory appears purposes of criminal prosecution as a means of prevention, ie prevention aimed at the general public. ${ }^{30}$ Theory combined (integrated) criminal basing on the principle of retaliation and the principle of defense order orderly society, in other words two reasons it became the basis of criminal punishment. Basically merger theory is a combined theory of absolute and relative theory. ${ }^{31}$ Treatment theory, suggests that very much deserved punishment directed at the perpetrators and not to his actions. This theory has a privilege in terms of the process of re-socialization of offenders that are expected to restore the quality of social and moral community to integrate back into society. According to Albert Camus, offenders Offender human remains, nevertheless as a human being, a perpetrator remains free also learn new values and a new adaptation. Therefore, the imposition of sanctions should educate Similarly, in this case an offender requires sanctions to be treatment. 32

\footnotetext{
${ }^{28}$ Dwidja Priyanto, Sistem Pelaksanaan Pidana Penjara di Indonesia (Bandung: Refika Aditama, 2009), 22.

${ }^{29}$ Leden Marpaung, Asas-Teori-Praktek Hukum Pidana (Jakarta: Sinar Grafika, 2009), 105.

30Marpaung, 106.

31Marpaung.

32Marpaung, 107.
} 
Yusi Amdani

Based on the theories of sentencing set forth above, it can be seen that the purpose of punishment itself formulate a policy mix between penal and nonpenal in regards to tackling crime. This is where the role of the state to protect the public by enforcing the law. Law enforcement officials are expected to tackle crime through a container of the Criminal Justice System.

As the opinion of Tjatur Sapto Edy mention that the House welcomed the political will of governments in terms of amnesty for Minimi Din and his group. The more political amnesty, but with the current state, a step President Jokowi it would be more effective than having to wait for the legal process and the lack of verification of the general crime committed. He further revealed by the amnesty is no one hurt, because of the amnesty granted by the principles of fairness, benefits, effective and efficient, so that the perpetrators of the separatist movement can return to normal life in society. ${ }^{33}$

However Tuti Niswati and Isnawati widows of two members of Kodim 0103 North Aceh, who was shot in the interior Nisam, Aceh Utara, a few months ago, will meet President Joko Widodo and TNI chief Gen. Gatot Nurmantyo. Both members of the military who allegedly shot dead by armed groups Ismali alias Nurdin bin Din Minimi. The purpose is to meet the President to inquire directly about granting amnesty to a group suspected of killing their husbands. "We are also going to ask the TNI Commander of the rule of law against the perpetrators who killed our husbands," said Tuti who was also accompanied Isnawati. ${ }^{34}$

Meanwhile, National Police Chief Gen. Badrodin Haiti said legal proceedings against Din Minimi, the leader of a paramilitary group in Aceh is still being done even though the relevant surrender. Only, no leniency can be considered. It also expressed by Aryos Nivada, say, law enforcement on Din Minimi have to keep running. ${ }^{35}$ Aryos Nivada also discloses the process of law

33Aditya Pratomo, "DPR Sambut Baik Pemberian Amnesti Din Minimi," Sentananews.com, 2016, accessed May 18, 2016, http://sentananews.com/news/news/dpr-sambut-baik-pemberianamnesti-din-minimi-13233.

34Safrizal, "Janda Tentara Korban Pembunuhan Din Minimi Akan Jumpai Presiden," AJNN.net Portal Berita Aceh, 2016, accessed August 26, 2016, http://www.ajnn.net/news/janda-tentarakorban-pembunuhan-din-minimi-akan-jumpai-presiden/index.html?D22901.

35Muhammad Hafil, “Din Minimi tetap Diproses Hukum," Republika.co.id, 2015, accessed May 18, 2016, https://www.republika.co.id/berita/koran/hukum-koran/15/12/30/o05v8d1-din-minimitetap-diproses-hukum. 
enforcement for Minimi Din expected not to get the intervention of any institution. According to Aryos, enforcement against Din Minimi is the realm of the Police. That is, other institutions do not have the authority. ${ }^{36}$

Therefore, it is the duty of the police to process reports of complaints from victims of kidnapping and other crime. The amount of political content is more dominant in the context of resolution Din Minimi impressed override law enforcement, so it looks different treatment. It could be a precedent that is not good in law enforcement in Indonesia as well as the principle of legal certainty is difficult to achieve. In the concept and objective of sentencing one of its functions is the protection of crime victims and families and the state in this matter and law enforcement agencies are there as representatives of the public and victims to prosecute criminally rather than instead to protect the perpetrators to exclude liability. It is understood the discourse of granting amnesty from the President. So that on one hand the police rated "undecided" in the running due to authority whether to wait or not related to the decline of the amnesty policy.

As for schemes and concepts for resolving cases of criminal offenses committed by Din Minimi can be seen in Figure 1.

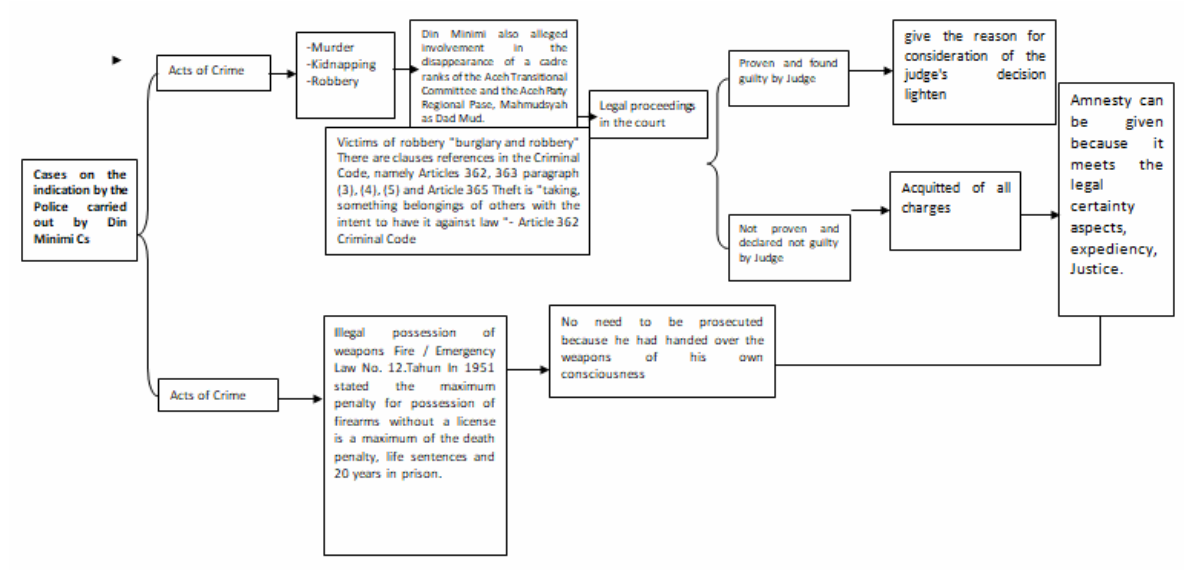

Figure 1.

Case Settlement Concept of Group Din Minimi

${ }^{36}$ Hafil. 
Referring to the concept of sentencing objectives mentioned above, in order to achieve the goal of law that includes fairness, certainty and legal expediency, then Din Minimi examination should be done by the police on criminal cases that have been done. Even though the President was about to give amnesty, should not disregard the criminal act has been committed by Din Minimi. It aims at least to provide certainty to the families and communities who have been harmed as a result of actions taken by Din Minimi.

\section{Conclusion}

Basic laws granting amnesty provided for in Article 14, Paragraph (2) Constitution of 1945. Amnesty is one of the absolute prerogative owned by the President as a form of pardon to political prisoners. Therefore, constitutional power of the President in the field of judicial owned, so it is associated with the participation of other institutions, namely the Supreme Court and Parliament in providing the legal and political considerations.

About granting amnesty for GAM has been stipulated in Presidential Decree No. 22 of 2005. Meanwhile, the planning amnesty for armed groups Din Minimi will be provided with a record of surrender to the government. However, when viewed in the legal aspect, amnesty if forced to give to Din Minimi, it is destructive to the prevailing laws in Indonesia. Do not rule out the possibility of regulation will hit Indonesia polemic, because it will be a lot of lawyers protested against the decision granting amnesty.

Based on the theory of punishment that any crime committed would be punished by type of crime. Therefore, granting amnesty to Din Minimi considered contrary to the concept of punishment, so it is feared will lead to legal uncertainty for victims of violence perpetrated by armed groups Din Minimi before granting amnesty.[a]

\section{BIBLIOGRAPHY}

Anonimous. "Mempertimbangkan Amnesti bagi Tahanan Politik Papua." Jakarta: Kontras, n.d.

Asshiddiqie, Jimly. Konstitusi dan Konstutionalisme Indonesia. Jakarta: Sinar Grafika, 2010. 
Darmanto. Sistem Administrasi Negara Kesatuan Republik Indonesia. Jakarta: Universitas Tebuka, 2007.

Deliani, Dhian. "Pelaksanaan Kekuasaan Presiden dalam Pemberian Grasi: Studi terhadap Pelaksanaan Pemberian Grasi oleh Presiden Susilo Bambang Yudhoyono Tahun 2004 s/d 2010." Thesis, Fakultas Hukum, Program Pascasarjana, Universitas Indonesia, 2011.

ELSAM. “Impunitas.” ELSAM - Referensi HAM, 2014. http://referensi.elsam. or.id/2014/09/impunitas/.

Ghofar, Abdul. Perbandingan Kekuasaan Presiden Indonesia setelah Perubahan UUD 1945 dengan Delapan Negara Maju. Jakarta: Kencana Prenada Media Group, 2009.

Hafil, Muhammad. “Din Minimi tetap Diproses Hukum.” Republika.co.id, 2015. https://www.republika.co.id/berita/koran/hukumkoran/15/12/30/o05v8d1-din-minimi-tetap-diproses-hukum.

Hasyim. "Amnesti untuk Din Minimi Hancurkan Reputasi Aceh." Serambi Indonesia - Aceh.Tribunnews.com, 2016. http://aceh.tribunnews.com/ 2016/01/02/amnesti-untuk-din-minimi-hancurkan-reputasi-aceh.

"Indonesia: Averting Election Violence in Aceh." International Crisis Group, 2012. https://www.crisisgroup.org/asia/south-east-asia/indonesia/ indonesia-averting-election-violence-aceh.

"Indonesia: GAM vs GAM in the Aceh Elections." International Crisis Group, 2011. https://www.crisisgroup.org/asia/south-east-asia/indonesia/ indonesia-gam-vs-gam-aceh-elections.

Manan, Bagir. Lembaga Kepresidenan. Jakarta: FH UII Press, 2003.

Marpaung, Leden. Asas-Teori-Praktek Hukum Pidana. Jakarta: Sinar Grafika, 2009.

Nivada, Aryos. “Amnesti bagi Din Minimi, Layakkah?” aceHTrend.com, 2016. https://www.acehtrend.com/2016/01/04/amnesti-bagi-din-minimilayakkah/.

Peuhaba. "Riwayat Lengkap Din Minimi di Aceh." Detik Semas $\alpha 2015$. https://seaceh.wordpress.com/2015/03/27/riwayat-lengkap-dinminimi-di-aceh/.Prang, Amrizal J. "Kontroversi Diskursus Amnesti Din Minimi." Serambi Indonesia - Aceh.Tribunnews.com, 2016. http://aceh.tribunnews.com/ 2016/01/19/kontroversi-diskursusamnesti-din-minimi.

Pratomo, Aditya. "DPR Sambut Baik Pemberian Amnesti Din Minimi." Sentananews.com, 2016. http://sentananews.com/news/news/dprsambut-baik-pemberian-amnesti-din-minimi-13233. 
Yusi Amdani

Prawira, Indra. "Amnesti dan Abolisi dari Perspektif Hukum Tata Negara." In Seminar Pengusulan Syafrudin Prawiranegara sebagai Pahlawan Nasional, Bandung, 16 Juni 2009. Bandung, 2009.

"Prerogative | Definition of Prerogative." Merriam-Webster. Accessed May 8, 2016. https://www.merriam-webster.com/dictionary/prerogative.

Priyanto, Dwidja. Sistem Pelaksanaan Pidana Penjara di Indonesia. Bandung: Refika Aditama, 2009.

Ranadireksa, Hendarmin. Visi Bernegara Arsiktektur Konstitusi Demokratik. Bandung: Fokus Media, 2009.

Ritonga, Abdul Rahman. Ensiklopedi Hukum Islam. Jakarta: Ichtiar Baru Van Hoeve, 1997.

Safrizal. "Janda Tentara Korban Pembunuhan Din Minimi Akan Jumpai Presiden.” AJNN.net - Portal Berita Aceh, 2016. http://www.ajnn.net/ news/janda-tentara-korban-pembunuhan-din-minimi-akan-jumpaipresiden/index.html?D22901.

Ash-Shiddieqy, Teungku Muhammad Hasbi. Filsafat Hukum Islam. Jakarta: Bulan Bintang, 1975.

Soekanto, Soerjono. Pengantar Penelitian Hukum. Jakarta: UI Press, 1986.

Susetyorini, Herawati. "Perbandingan Teori Pemidanaan Menurut Hukum Pidana Islam dan Kitab Undang-Undang Hukum Pidana (KUHP)." Thesis, Universitas Muhammadiyah Malang, 2004. http:// eprints.umm.ac.id/19720/

Syafiq, Ahmad. "Rekonstruksi Pemidanaan dalam Hukum Pidana Islam (Perspektif Filsafat Hukum)." Jurnal Pembaharuan Hukum 1, no. 2 (August 1, 2014): 178-90. https://doi.org/10.26532/jph.v1i2.1484.

Tim Liputan BBC News Indonesia. "Kelompok Eks Kombatan GAM, Din Minimi Menyerahkan Diri.” BBC News Indonesia, 2015. https://www.bbc. com/indonesia/berita_indonesia/2015/12/151229_indonesia_kelomp okdimini_menyerah.

'Ulya, Zaki. "Refleksi Memorandum of Understanding (MoU) Helsinki dalam Kaitan Makna Otonomi Khusus di Aceh." Jurnal Konstitusi 11, no. 2 (2014): 371-92. https://doi.org/10.31078/JK\%X. 